\title{
実験的皮膚真菌症に対する性腺刺激ホルモン ならびに性ホルモンの影響について
}

\author{
大久保洋平嶋崎匡 \\ 北海道大学医学部皮膚科教窒（主任 三浦龵晶教授）
}

\section{I. 緒言}

近年, ACTH, コーチゾンをはじめ, 種くのホルモ ンの真菌感染に対する影響が注目されてきた，皮膚科領 域においても, 臨床的あるいは実験的に多数の研究がな されているが，多くはACTHおよび副腎皮質ホルモン

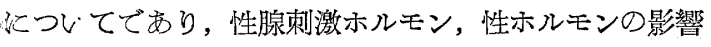
炇関する報告は少ない上らである。

われわれはいくつかの表在性皮膚真菌症, たとえば頭 部白鰠㤂纤年者に多く, 小わゆる水虫が成人に好発し, また頑漁が男性に優位字示すここから, 白痽に扣ける host-parasite relationship こ性腺刺激ホルモンおよび 性ホルモンの関連性重視し, Trichophyton mentagrophytes を用いて in vitro ならびそ in vivo の実験的 灌察を㧍こなつた。

\section{II. 試験管内実験}

性腺刺激ホルモン, 性ホルモンの白癬菌発育に対する 宿接的影響崖觀察した。

\section{1. 実験方法}

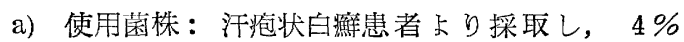
Sabouraud ブドウ糖寒天斜面培地に接種して, $25^{\circ} \mathrm{C}$, 30日間培養を扢しなつた Trichopyton mentagrophytes 安使用した。

b) 使用ホルモン郕：ゴナドトロピン(ゴナーゲンフ オルト注射液), ビベンジル誘導体 (水溶性ロバール注射 液）扢よびプロピオン酸テストステロン（エナルモン水 性㲘䎂注射液）を使用した。

c) 培養方法：9 cm規格型シヤーレを用い，4\% Sabouraudブドウ糖寒天 $25 \operatorname{cc} の$ 平板培地 4 個作製し, 対照培地とした．別に寒天 $1 \mathrm{cc}$ 当りゴナドトロピンを50 ラッテ単位，5ラッテ単位抬よび 0.5ラッテ単位をそれ ぞれ混和した平板培地定各 4 個, おなじくエストロゲン
表 1 性腺刺激ホルモンならびに性ホルモン添 加培地に打汀る白淮菌発育の比較 $\left(25^{\circ} \mathrm{C}, 15\right.$ 日)

\begin{tabular}{|c|c|c|c|}
\hline $\begin{array}{c}\text { ゴナドトロ } \\
\text { ピン添加 }\end{array}$ & $50.0 \mathrm{RU} / \mathrm{cc}$ & $5.0 \mathrm{RU} / \mathrm{cc}$ & $0.5 \mathrm{RU} / \mathrm{cc}$ \\
\hline 1 & $19.3 \mathrm{~mm}$ & $20.5 \mathrm{~mm}$ & $25.4 \mathrm{~mm}$ \\
2 & 22.4 & 22.2 & 27.3 \\
3 & 19.0 & 24.0 & 26.4 \\
4 & 20.4 & 19.3 & 25.0 \\
\hline 平 均 & 20.3 & 21.5 & 26.0 \\
\hline
\end{tabular}

\begin{tabular}{|c|c|c|c|}
\hline $\begin{array}{c}\text { エストロゲ } \\
\text { ソ添加 }\end{array}$ & $500.0 \mathrm{U} / \mathrm{cc}$ & $50.0 \mathrm{U} / \mathrm{cc}$ & $5.0 \mathrm{U} / \mathrm{cc}$ \\
\hline 1 & $29.0 \mathrm{~mm}$ & $27.2 \mathrm{~mm}$ & $23.7 \mathrm{~mm}$ \\
2 & 25.7 & 28.1 & 26.1 \\
3 & 28.0 & 25.5 & 25.2 \\
4 & 25.2 & 29.1 & 24.3 \\
\hline 平 均 & 27.0 & 27.5 & 24.8 \\
\hline
\end{tabular}

\begin{tabular}{|c|c|c|c|}
\hline $\begin{array}{l}\text { テストステ } \\
\text { ロン添加 }\end{array}$ & $50.0 \mu \mathrm{g} / \mathrm{cc}$ & $5.0 \mu \mathrm{g} / \mathrm{cc}$ & $0.5 \mu \mathrm{g} / \mathrm{cc}$ \\
\hline 1 & $25.1 \mathrm{~mm}$ & 計測不能 & $27.7 \mathrm{~mm}$ \\
2 & 26.0 & 27.1 & 30.1 \\
3 & 27.5 & 27.8 & 28.4 \\
4 & 26.3 & 26.9 & 27.0 \\
\hline 平 均 & 26.2 & 27.3 & 28.3 \\
\hline
\end{tabular}

\begin{tabular}{|c|l|l|l|}
\hline 対 照 & & & \\
\hline 1 & $24.6 \mathrm{~mm}$ & \\
2 & 25.1 & \\
3 & 26.0 & & \\
4 & 24.4 & & \\
\hline 平 均 & 25.0 & & \\
\hline
\end{tabular}

Yohhei OHKUBO \& Tadashi SHIMAZAKI: INFLUENCE OF GONADOTROPIC AND SEXUAL HORMONE TO EXPERIMENTAL DERMATOMYCOSIS. From the Department of Dermatology (Director: Prof. Y. MIURA), University of Hokkaido Medical School, Sapporo-Japan. J. Med. Mycol. 5, 1964. 
导500単位，50単位祆よび5単位，テストステロンを $50 \mu \mathrm{g} ， 5 \mu \mathrm{g}$.拉よび $0.5 \mu \mathrm{g}$ をそれぞれ混和した培地字各 4 個宛作製し，さきの Trichophyton mentagrophytes のコロニーの一笔星に生理食壏水老加えて充分 homogenate して浮游液学作り, それぞれの平板培地の中央に 規格環状白金耳を用いて 1 白金耳量を接種し， $25^{\circ} \mathrm{C} て ゙ 15$ 日間培養尘捛こなつた。

\section{2. 実験成績}

増殖したコロニーの直径学直角の 2 方向より計測, 比 較した (表 1 ).

対照コロニーの直径平均值が $25.0 \mathrm{~mm}$ であるのに対し て, ゴナドトロピ.ン添加のものは50シッテ単位で 20.3 mm, 5 ラツテ単位で $21.5 \mathrm{~mm}$ 己かなり発育抑制傾向がみら れた.エフトログン稆よ゙テストステロン添加では刘照 に比較しててコロニーがや〉大きい.

各コロニーの一部党検鏡し, 菌の形態的変化を觀察し たが, 菌糸の curling, 異常分枝などは及られず, 菌成 長に直接的影響はおよぼさないようである。

\section{III. 動物接種実験}

実験的動物白瘖に対する性腺刺激ホルモン, 性ホルモ ンおるび性腺摘出の影響を觀察した。

\section{1. 実験方法}

a) 使用菌株：II. . 同一のものを使用した。 b) 使用ホルモン剂：II 。乙同一のものを使用した。

c) 使用動物：体重 $450 \mathrm{~g}$ から $600 \mathrm{~g}$ までの雄モルモ ツト岂用いた。飼料注市販えん麦己水の及に限定し，実 験施行の 2 週前から奏験終了時息で投与した. 正常対照 群以外注, 分泌る性ホルモンの影響泽除く目的で, 菌接種の 2 週前宗でに性腺摘出（除辠術）を抬こない, 手術侵睝が除去されたと考えられる術後 2 週以上圭経た もの学試験に供した。

d)，実験操作 : モルモット10匹学 1 群として, 正常対 照群, 性腺摘出群, 性腺摘出ゴナドトロピン投与群, 性 腺摘出エストログン投与群，性腺摘出テストステロン投 与群の5群に分仯，ホルモン投与群に经体重 $1 \mathrm{~kg}$ 当りゴ ナドトロピンを 1,000ラッテ単位，エストロゲンを 10,0 00単位, テストステトンを $1 \mathrm{mg}$ 宛 3 日間連続皮下注射を 扮てなつた。 5群のェルモットの背部䒚拔毛したのち, 出血しない程度に sand paper で擦過し, Trichophyton mentagrophytes 生理食塩水浮游液の一定量安擦り込 及, 接種を扟となつた。 その後, 各ホルモン投与群に対 して同単位のホルモン量孛隔日に合計11回にわたり皮下 に注射した.

\section{2. 実験成績}

上記 5 群について, Trichophyton mentagrophytes 接 種から菌要素の消失までの経過学觀察した（図1).

図 1 対照群, 性腺摘出群, 性腺摘出後性腺刺激ホルモン投与群ならびに性腺摘出後性ホルモン投与 群に扣ける実験的白絴病変の推移

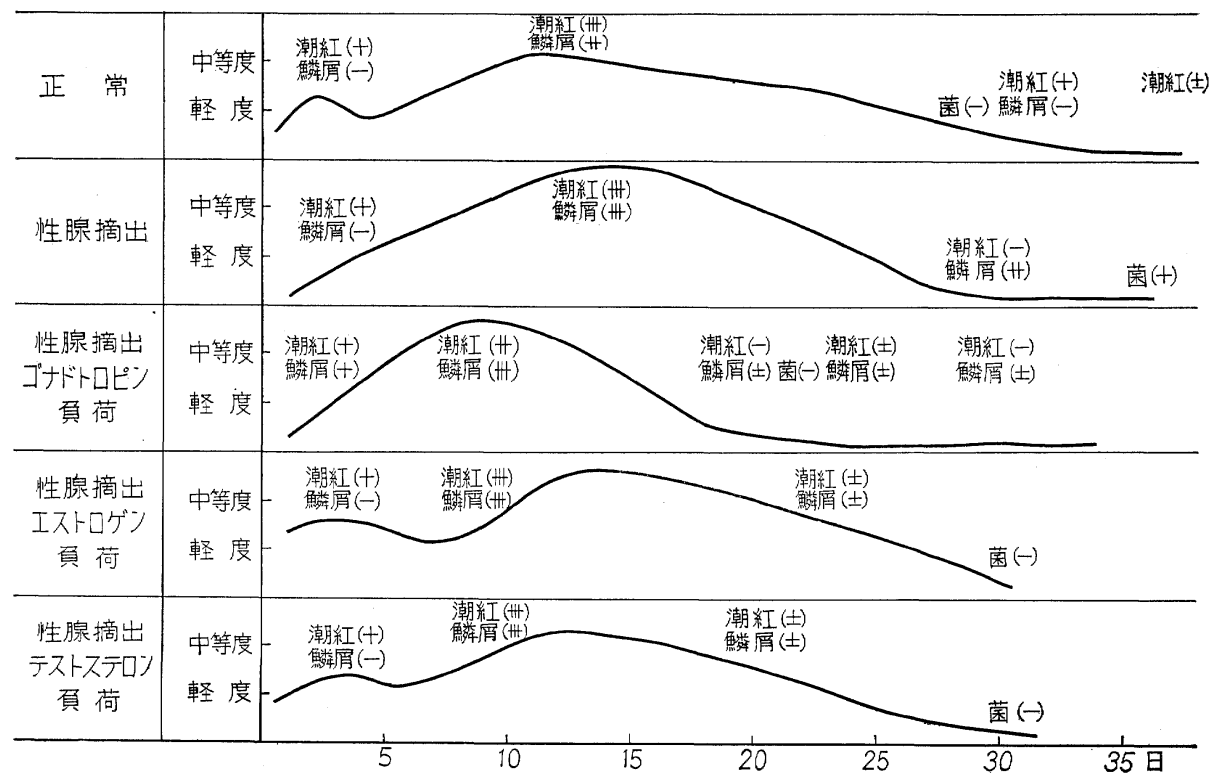


a) 正常対照群：菌接種 4 日目态でに sand paper 擦 過による炎症及状が緩解して来るが，5日目ないし 6 日 目より次第に湖漫性の潮紅をさたすとともに鱗屑导認め るようになり，12日目に压涪症状は極期となる，その 後, 漸次軽快してゅき, 35日目にははとえど治瘾した。 鱗屑中の菌要素は29日目に陰性となつた。

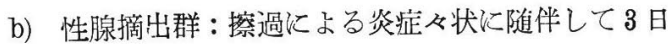
目上り潮紅が増強し，13日目で潮紅，能屑とも強度とな う，数日間同じ状態在保つたのち，16日目頃から軽快し て行くが, 30 日目に至つてもな扢, かなり多くの鱗首が 残存し, 菌要素は35日目でな揚性であつた。

c) 性腺摘出ゴナドトロピン投与群 : 他群に較べて皮 膚症状は急速に進行し，8 日目に極期に達する．10日頃 から比較的急速に症状以軽快し，23日目には添とんど治 癒した。觶眉中の菌要素は22日目で陰性となつた。

d) 性腺摘出エストロゲン投与群: 接種後 7 日目頃 では軽度の潮紅をみる程度に経過するが, 8 日目頃かる 潮紅, 鳞屑が頙著己なり, 11日目に極期に達した。 約 3 日間同じ症状を経過してから次第に治癔傾向を示し, 26 日目に核治治癒した。菌要索注29日目に陰性となつた。

e) 性腺摘出テストステロン投与群 : 擦過に上る炎症 ふ状に引き続いで，7日月頃から皮膚病変が強まり，10 日目に著明となるが, 他群に較べて症状はや〉軽度であ り，次第に軽減して行く．25日目を経てからは特徽的な 皮膚変化は久られず，31日目に菌要素は陰性さなつた。

\section{3. 小括}

a) 性腺摘出群は対照溶ぐて症状の增惡がや>早 く, かつ白㿑の経過が長い.

b) 性腺摘出群および性腺摘出コナドトロピン投与群 は対照に輘べ鳞屑が著明に増加する。

c) 性湶摘出ゴナドトロピン投与群は対照に輅べて症 状の発来がや>早々, 極期に至るのも若干はやいが, 症状 の消袏, 菌要素の消失する末での期間が短縮されている.

d）性腺摘出エストロゲン投与群ならびに性腺摘出テ ストステロン投与群では, 皮膚症状, 経過は対照と較べ 明巨かな差異を示さない。

各群に打方白㾕菌接種後 10 日目の皮膚所見を図 2,3 , $4,5,6$ 亿示す。

以上から性腺摘出 (除宰) モルモツトでは白鷹の発症 が容易となり, 病変や〉強く, 経過も長くなるととか ら，テストステロンに in vivo に扮汀る白鷹菌発育阻 止作用のあることが推測される。 またゴナドトロピンは 症状の軽重には明巨かな差異を示さないが, 経過の短縮
図 2 正常対照群

菌接後に10日目。全経過中のほぼ極期に近く、背部 に酒漫性の湖紅と中等度の鱗屑が存在する。

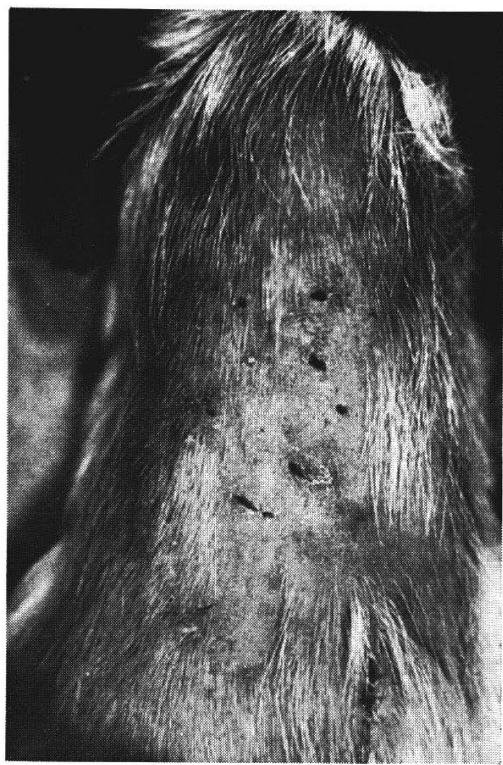

図 3 性腺摘出 (除堹) 群

菌接種後 10 日目。極期に至らないが, 他群に較べて 潮紅, 鱗屑とも著明に認められる。

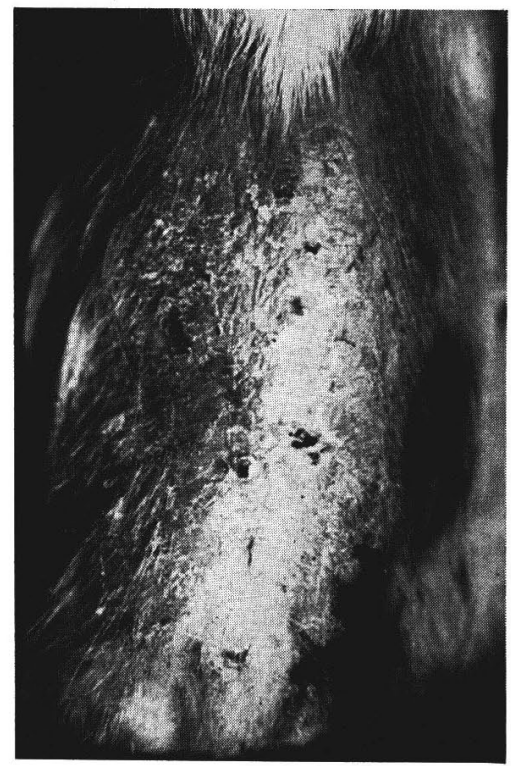


図4性腺摘出ゴナドトロピン投与群 菌接種後 10 日目. 他群より子炎症症状は急速に経過 しすずに潮紅は軽度となつている。

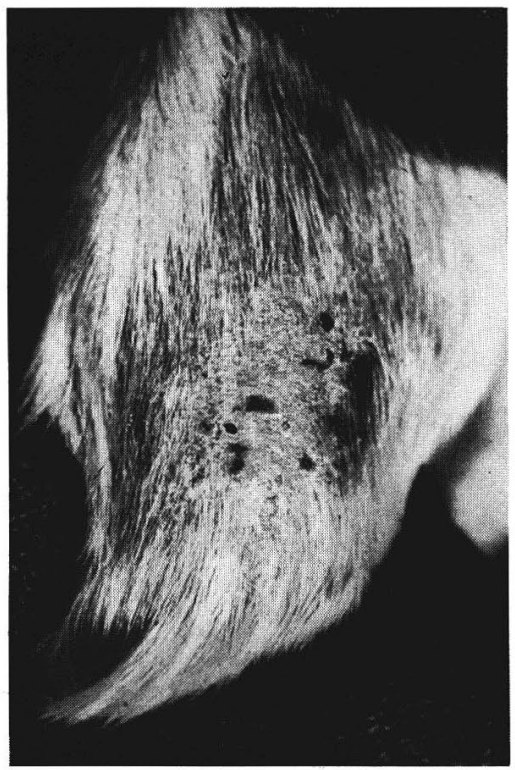

図 5 性腺摘出エストロゲン投与群 菌接種後10日目。ほぼ極期に達するが症状の程度は ほとんど対照群に類似する。

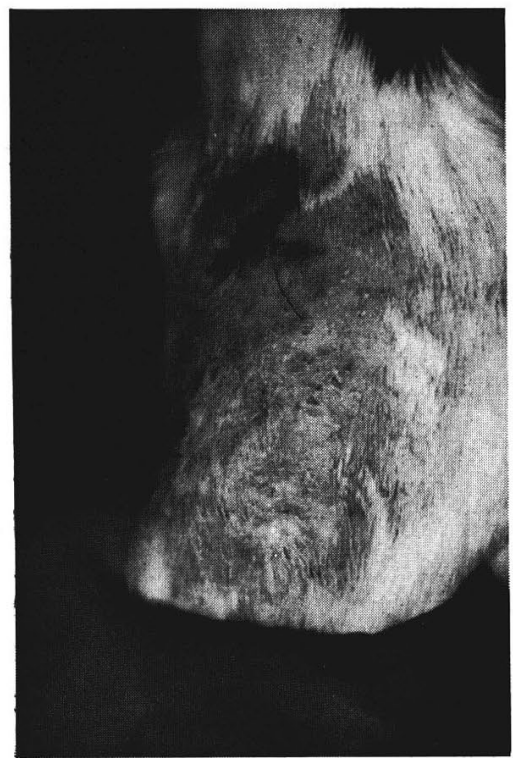

図 6 性腺摘出テストステロン投与群 菌接種後10日目。極期症状であるが，他群よりも炎 症症状はやや軽度である。

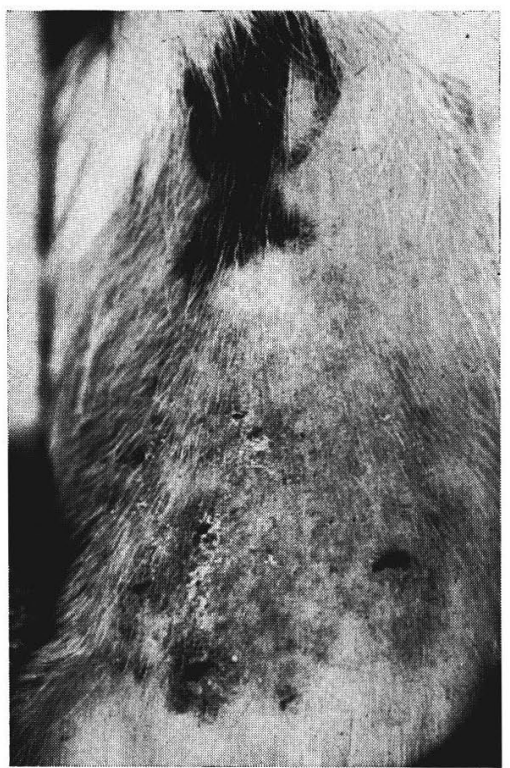

が夕られ，白癬菌発育阻止作用のあることが推定され た.

\section{IV. 総括ならびに考按}

真菌症と内分泌機能乞の関係は, 治療こして種々の木 ルモン夙を使用した際に，あるいはまた内分泌機能障碍 疾患時にしばしば真菌症の併発をみるここからも重要視 されるようになつて来た，たとえば副腎皮質ホルモンに 関しては, Zimmerman'1 はコーチゾン長期連用患者に moniliasis あるいは aspergillosis の発症孛, Burns ${ }^{21}$ は cryptococcosis 学, Cremer ${ }^{3)}$ は沉発性白癄の発症览 みたととを述べ，最近，Jung \& Truniger ${ }^{4)}$ は典型的 Cushing 症候群患者に瘄風の発症をみたが，Cushing 症候群の治癒とともに癜風も消失したことを記載して揖 り，内分泌機能が真菌感染昰になんらかの影響を拉よぼ していることが窺われる.

先に述べた如く表在性白痽のいくつかが，年令，性別 に特異性を示专実から, これら真菌症と性腺刺激ホル モンおよび性ホルモンとの関係が注目されるようになつ た。これまでの報告をみると, Poth ら5゙は頭部白㵲と 性ホルモンの関連性に着目し，30例の患者に対して estrogen, diethylstilbestrol を経口的に, または外用し て $87 \%$ の有効率を得たと報告して扔り, その理由として, 明らかではないが estrogen が反心の場に㧤ける細胞の 
局所抵抗性を兽強するためであるうと述心゙ている。野口 $ら^{67}$ 活 diethylstilbestrol $\&$ estrodiol $の$ in vitro $に$ 招ける抗菌試験导試及, 日本小芽胞菌に対し diethylstilbestrol では 800等位/ccで菌発育阻止を認め, estrodiol では 6,667単位/ccで阻止をみた。しかし Trichophyton gypseum でね, 前者は 2,200単位/ccで発育を阻止した が, 後者では 500,000単位/ccでも阻止できなかつたとと を述べている.

ま它 Rebell ら") Trichophyton mentagrophytes, Micrococcus canis, Candida albicans, Cryptococcus neoformans, Blastomyces dermatitidis, Histoplasma capsulatum, Coccidioides immitis, Nocardia asteroides の菌株を用いて16種のステロイドによる試験管内発育試 験を括とない, $\Delta^{5}$-pregnene-3 $\beta, 20 \alpha$-diol-3-methylether 抢よび $3 \beta$-methoxy-17 $\beta$-hydroxy- $\Delta^{5}$-androstene- $17 \alpha$ acetic acid の2 種のホルモンに菌発育阻止効果を認め ているが，てれに対し Mayer ${ }^{8)}$ は長鎖脂肪酸とアミン 類良い抗菌因子として知られているが，てれらのステ ロイド作用は長鎖脂肪酸と化学的仙類似しているためだ ろろとし, stilbestrol 法テストステロンと同程度伉菌 作用が強力であるこの意見を述べている。またJahnke ${ }^{97}$ はェストロン䇽よびアンドロステロンは Trichophyton interdigitale と Microsporum gypseum の発育肉眼 的漌亦抑制し, 顕微鏡的に Mycelversporung ट菌 䊽成の掋大をみたが, Trichophyton rubrum では 源とんど変化を認めず，菌種に上る差異を示唆してい る. 樋口 ${ }^{10)}$ なびと植松 ${ }^{11}$ 变 Trichophyton gypseum,

Trichophyton purpureum 捛よび Microsporum fulvum の 3 株を用いて試験管内抗菌作用を觀察し,プレホルモ ン 33 ラツテ単位 $/ \mathrm{cc}$, エナルモン $0.3 \mathrm{mg} / \mathrm{cc}$, オバホルモ ン 667単位/ccを添加して培養をおこなつたが, との濃度 では明らかな差異を認めて扔らず，動物試験においてプ レホルモン 500ラッテ単位, テストステロン・プロピオ ネート $5 \mathrm{mg}$ (エナルモン), オバホルモン・ベンツアート 1 万単位を連日投与して觀察したところ, プレホルモン とオバホルモンが感染を容易さするが, エナルモンは抑 制傾向を示し, また除梓術が感染を促がすととを指摘し ている.

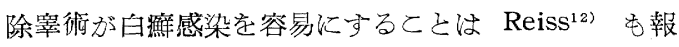
告しており, 病変の程度も強くかつ経過も長いと云う。

われわれの実験によると in vitro では対照のコロニ 一に比較してゴナドトロピン添加の場合に発育抑制傾向 が窥われ，エストロゲンおよびテストステロン添加では
幾分促進される如き結果を得たが，ゴナドトロピン拣ざ の差異以認めず，エストログン捛よびテストステロンは

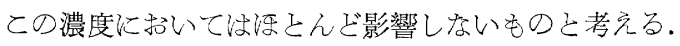
また菌糸の形態注何れも curling, 異常分枝注全く認め なかつた。

in vivo では性腺摘出（除睪）モルモツトの場合に対 照に較べて白痽症ふ状の増惡が幾分早く, かつ全経過は 延長されて, 植松, Reiss 等の意見々一致して, 感染を 容易とし，従つてテストステロンに白撚症抑制作用のあ るととが推測された。

性腺摘出ゴナドトロピン投与の場合牥炎症从状の極期 の到来淰早いが, 治癒過程も著るしく短縮されるととか ら，ゴナドトロピンが抑制効果孛有するもの上思われ た。しかしながら, Poth らが頭部白癬にエストロゲン が拮抗するとの報告に接し，われわれは雄モルモツトの 性腺摘出後にエストログンを投与した場合には, 実験的 白镂に执いても当然有效性を示すと乞予想したのであ るが, 結果は対照群と比較してなんら変らないととを觀 察した.

ところでこれらホルモンの感染に対する作用機序につ いて定説はなく, host, parasite の何れ作用寸るのか も異論のある己ころである. in vitro の真菌に対する 直接作用で Jahnke はニストロンおよびアンドロステ ロンのそれぞれ0.21mg\%，2.3mg\%添加12日間培豪の結 果, Microsporum gypseum ならびに Trichophyton interdigitale に発育抑制をみ，アンドロステロン添加 時に両菌株飞短かい不規則な分枝が生ずることを觀察し ているが, Trichophyton rubrum ではみられず，菌株 により異なる点を指摘している。また野口注菌株の差と 添加ホルモン濃度によつて発育状態が相異したことを挙 げている。

われわれはゴナドトロピン添加の際に発育抑制傾向を 觀察したが, 菌糸発育異常は認めず, これらのホルモン

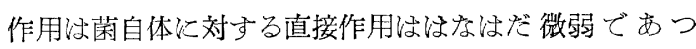
て, 主体はむしろ host 亿対する影響であろろと想像す る。高橋こ ${ }^{13}$ 任モルモツト紎菌症に招ける副腎皮質小 ルモンの影響を觀察し, 経過中のプレドニソロン負荷時 期により個体免疫性が変動するととを述い゙ている。

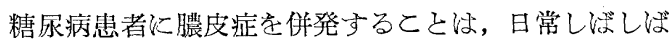
経験するこしろであるが, 当教室の大浦 ${ }^{14}$ そよればゴナ ドトロピン投与時に皮虐精扮よび皮㲊含水量の変動をき たし，なかんづく皮署糖は増加するとされる。このとと から，あるい浪われれぶゴナドトロピンに真菌抑制傾 
向を觀察したのは，菌発育の至適皮膚糖值の変動に起因 するのではなかららかと推察される。

\section{V. 結語}

われわれ《性腺刺載ホルモン括よび性ホルモンの

Trichophyton mentagrophytes に対する影響を in vitro ならびに in vivoで觀察した結果，次の成績を得た。

1）試験管内実験でゴナドトロピンは菌発育をや〉抑 制したが, 菌系の形態的変化は認めなかつた。

2）動物実験では，除悬術は感染を容易こした。

3）ゴナドトロピンは対照に比して, 実験的白㾋の症 状をや〉早期に発来せしめ, その経過学短縮する.

4）エストログンならびにテストステロンは刘照に比 較して, 試験管内でも，動物実験に括いても著差が認め られなかつた。

5）ゴナドトロピンは皮膚糖の変動をきたし，その結 果白癬菌発育が抑制されるのではないかこ考える.

稿を終るに当り終始御指導を戴いた柇幌斗南病院皮膚 科医長小野塚伦博士に謝意を表します。

(本論文の要旨は第152回日本皮膚科学会北海道地方会 ならびに第 5 回日本医真菌学会総会に打いて発表した).

\section{文 献}

1) Zimmerman, L.E.: Am. J. Clin. Path., 25, 46, 1955.

2) Burns, R.E.: A.M.A. Arch. Dermat., 77, $686,1958$.

3) Cremer, G.: Dermatologica, 111, 285, 1955.

4) Jung, E.G. \& Truniger, B.: Dermatologica, $127,18,1963$.

5) Poth, D.O. et al.: 11) ょり引用.

6）野口義图：化学療法, No. 17, 6, 昭33.

7) Rebell, G. \& Lamb, J.H.: J. Invest. Dermat., 21, 331, 1953.

8) Mayer, R.L.: 7)ょり引用.

9) Jahnke, G.: Mykosen, 2,7,1959.

10）樋口謙太郎: Chemotherapy, 6, 189, 昭33.

11）植松一男：皮と泌，20，524,昭 33 .

12) Reiss, F.: 11) ょり引用.

13）高橋吉定, 高橋伸也, 稲城矩実 : 真菌誌, 1,42 , 昭 35 .

14）大浦武浐：日皮会誌，70，468；735, 昭35.

(昭和39年 4 月 23 日受付) 